\title{
The Impact of AVID Tutoring on Developing a Teacher Identity
}

\begin{abstract}
There is extensive research demonstrating the benefits tutoring has on the tutee. However, much less research exists about the impact tutoring has on the tutor, and particularly, how being a tutor influences pre-service teacher development during teacher preparation. Using qualitative measures, this study documents the influence participating in the tutoring program, Advancement Via Individual Determination (AVID), has on a pre-service teacher's development of their teacher identity, particularly in the areas of pedagogical knowledge and practice. This study reveals how the AVID tutoring program influenced the tutors' development of their teacher identity, implications of the findings, and areas for future research and practice.
\end{abstract}

Keywords: Tutoring; AVID; Teacher Identity; Teacher Preparation; Qualitative Research

\section{Introduction}

Due to the importance of developing high quality teachers, the process through which teachers develop has been a critical research focus. The area identified as one of the most influential factors in teachers' development is the teacher preparation program (Beauchamp \& Thomas, 2009; Danielewicz, 2001; Putnam \& Borko, 2000; Wideen, Mayer-Smith, \& Moon, 1998). Therefore, it is important to understand how the experiences during a teacher preparation program lead to a more efficient development of a teacher identity and in turn produce more highly qualified teachers. Careful consideration should be given to the types and timing of the 
experiences provided for pre-service teachers to maximize the development process (Beltman, Mansfield, \& Price, 2011; Izadinia, 2013; Mansfield, Beltman, \& Price, 2014).

One common activity in which pre-service teachers participate is being a tutor. Tutoring is an altruistic endeavor that has the potential to benefit both those receiving the tutoring and those who do the tutoring. Research about the benefits of the tutoring process focuses mainly on the benefits to the student being tutored. Much less research has been conducted on how the tutoring process impacts the tutor, but indicates tutoring has a positive impact on the tutor in regards to teacher development. Lin, Lin, and Lu (2015) called the process of teacher development "competence building", while others refer to it as developing a "teacher identity" (Chong, Low, \& Goh, 2011; Izadinia, 2013). Building a teacher identity involves several different components. For example, tutoring helps tutors learn about teaching (Massey \& Lewis, 2011), exposes them to new ideas about teaching and learning such as developing instructional routines and teaching methodology (Trent, 2010; Walkington, 2005), and can prepare pre-service teachers for teaching (DeFeo \& Caparas, 2014; Ragonis \& Hazzan, 2009). This study builds on the rationale that during teacher preparation programs, it is common and beneficial for preservice students to participate in programs as a tutor. However, the specific benefits on the tutor from being part of a tutoring program have not been widely researched. Therefore, we document the how being an Advancement Via Individual Determination (AVID) tutor during a teacher preparation program influenced the pre-service teachers' development of their teaching identity.

\section{Research Question}

This research project focused solely on the impact of one tutoring program on the tutor. The tutoring process studied in this project is the AVID program. Although many articles have been published about AVID, they focus on topics such as the students receiving the tutoring, 
principal leadership, and AVID elective teachers; very little research has examined the impact on the tutors. The primary research question for this study was: What impact did AVID tutoring have on tutors in the formation of teacher identity?

\section{Teacher Identity}

As pre-service teachers practice the act of teaching, they build their teacher identity (Chong et al., 2011; Izadinia, 2013). This practice allows them to develop a way of thinking that determines what kind of teacher they will be. There are several definitions and characteristics of teacher identity, which include what content they will teach, the pedagogical practices they will use in the classroom, the way they develop relationships with their students, and the way they engage with their colleagues within the educational community (Beijaard, Meijer, \& Verloop, 2004). Teacher identity also determines "where they place their effort and whether and how they seek out professional development opportunities" (Hammerness, Darling-Hammond, \& Bransford, 2005, p. 384). Teacher identity is not a predetermined characteristic (Beauchamp \& Thomas, 2009; Beijaard et al., 2004; Maclean \& White, 2007; Olsen, 2008; Rodgers \& Scott, 2008), but instead is a constantly evolving process based on behaviors developed while learning to teach (Findlay, 2006; Gee, 2000; Schepens, Aelterman, \& Vlerick, 2009; Smagorinsky, Cook, Moore, Jackson, \& Fry, 2004; Trent, 2010; Walkington, 2005). Mayer (1999) reported that a teacher's identity is a personal characteristic, rather than the technical functions performed by a teacher, that demonstrates how one feels about being teacher. These characteristics are continuously being formed and reformed through a variety of experiences. Ultimately, these ideas form as pre-service teachers begin to navigate understanding of how their personal views and beliefs of teaching interact with the expectations of the profession (Pillen, Beijaard, \& den Brok, 2013). 
Tutoring. The tutoring experience provides a real world setting for learning teaching practices (Massey \& Lewis, 2011). Lane, Hudson, McCray, Tragash, and Zeig (2011) noted that pre-service teachers who tutored also enhanced their perceptions about themselves as teachers; furthermore, tutors felt a sense of achievement when their tutees were successful (Lin et al., 2015). Bar-Eli, Bar-Eli, Tenenbaum, and Forlin (1998) found that the in-service teachers with which these tutors interacted supported them in developing their teacher identity.

In addition to gaining knowledge about teaching practices, the tutors grew in their own understandings of content specific knowledge (Cohen, Kulik, \& Kulik, 1982; Massey \& Lewis, 2011). Tutors were motivated to learn the material better because of the responsibility they felt as a tutor (Galbraith \& Winterbottom, 2011). Through a comprehensive meta-analysis, Cohen et al. (1982) discovered that in 33 of the 38 studies included in the research study, students who served as tutors performed better on subject area tests than students who did not tutor. Bar-Eli et al. (1998) also determined that with proper preparation, tutors demonstrate a substantial increase in their performance on task-related academic activities. Galbraith and Winterbottom (2011) established that tutoring enabled tutors to identify weaknesses in their understanding of content. Tutors were then able to develop more positive attitudes toward that content (Cohen et al., 1982), likely contributing to increased feelings of competence.

Other benefits of tutoring revolve around strengthening relationships with the students, school, and community. Rothman and Henderson (2011) found that tutors who have knowledge of the course standards, familiarity with the associated curriculum and an ongoing relationship with the tutees, were more likely to create a positive bond with the students. Tutors also increased their knowledge about students and the diverse ways students learn (Lane et al., 2011). With this increased knowledge of student learning, tutors developed transferable skills, allowing 
for a reasonable conclusion that pre-service teachers who tutor will bring useful teaching skills and ideas into their future classrooms (DeFeo \& Caparas, 2014). If tutoring is done at a school site, tutors have the potential to gain awareness of the school system, practice building relationships with students, teachers, and parents, and increase their sense of commitment to the community. College students become more engaged with the community when they tutor (Lin et al., 2015). The tutoring process also allows colleges and universities to connect with the community by building partnerships with educational stakeholders (Lane et al., 2011).

\section{The AVID Program}

AVID follows a particular model and requires specific elements for the school to follow when implementing the program. The following sections describe the specifics of the program, the involvement of the tutors and documented benefits.

\section{Description and Purpose}

AVID is nonprofit educational program designed to close achievement gaps and provide additional post-secondary opportunities for students by increasing college readiness (AVID, 2017). For a school to be eligible to offer the AVID program, they must undergo an extensive initial certification program and complete an annual site self-study of their implementation of the AVID Essentials. To qualify as an AVID site, and to ensure maximum impact on students, the school must demonstrate the 11 AVID Essentials as described by the AVID program. These include parameters such as focusing on students in the academic middle, participation from students and staff must be voluntary, AVID classes are embedded in the regular school day, having a sufficient amount of AVID tutors to promote the appropriate level of collaboration and class size, and other essential aspects to maintain the integrity of the program (AVID, 2017). 
AVID creates learning environments for students that need additional support in order to increase their academic achievement. AVID is primarily focused on students who are academically in the middle of their class and have a high interest in attending an institution of higher learning. Students apply for the AVID program and are selected based on academic promise and risk factors related to attending post-secondary education. In addition to receiving regular tutoring, the students attend an AVID elective class where students receive the additional academic, social, and emotional support to help improve their chances of success in their school's most rigorous courses (AVID, 2018). Joining the AVID program requires a commitment from the students that goes beyond traditional "as needed" tutoring. Not only do AVID students regularly attend their AVID elective class throughout the school year, they also attend regularly scheduled tutoring sessions and enroll in classes that put them on track for college readiness ([Director], personal communication, February 18, 2013). Ideally, students enter AVID early and remain in the program through high school graduation.

\section{Impact and Benefits of Participating in AVID}

AVID is offered all across the United States in addition to internationally. In the United States, there are currently 6,268 AVID programs serving over 1.2 million students. In 2016, AVID had 42,418 seniors enrolled in the program. Of those, $98 \%$ graduated on time and $79 \%$ were accepted into a 4-year institution of higher learning which is $11 \%$ higher than the national average (AVID, 2017). Of all AVID graduates, $85 \%$ of those attending an institution of higher education persisted into the second year, compared to the national average of $78 \%$ (AVID, 201). In addition to the descriptive data provided by the AVID organization, other research has reported the benefits of the program. Research indicates that AVID students have been able to outperform their peers on standardized tests, attendance rates, and on-time graduation rates, as 
well as demonstrating success in more rigorous coursework (Watt, Powell, \& Mendiola, 2004;

Watt, Yanez, \& Cossio, 2002). Schools implementing an AVID program reported having a more positive school culture and climate by creating an environment where ideas, values and beliefs are shared (Watt, Huerta, \& Mills, 2010a, 2010b). Schools with an AVID program also have more students enroll in Advanced Placement courses (Huerta, Watt, \& Butcher, 2013; Watt et al., 2004; Watt, Powell, Mendiola, \& Cossio, 2006) and have more students from underrepresented groups attend institutions of higher learning (Watt, Huerta, \& Lozano, 2007;

Watt et al., 2004; Watt et al., 2002).

\section{Classroom Environment}

AVID is different from most traditional tutoring models, varying in purpose and approach. When the term tutoring is used, the typical one-to-one homework help comes to mind. However, AVID tutoring is part of system that focuses on college readiness and features a unique approach to tutoring that includes both tutor training and tutee training as well as tutee support through an AVID elective class. AVID tutors undergo a training program in order to use proven practices in the classroom in order to prepare students for success in high school, college, and a career, especially students traditionally underrepresented in higher education. Tutees undergo training to understand the importance of being prepared for class, participating in class activities, and engaging in metacognitive thinking. In class, AVID tutors facilitate a small group of up to seven students. AVID students prepare for their tutoring sessions by writing questions they would like to address and recording what they already know that will help in answering the questions ([Director], personal communication, February 18, 2013). AVID tutorials are a time and place where students come with complex questions from any content class and get guiding support to confront tough problems and solve them within their own means. The tutors are able 
to create an environment where students feel comfortable asking the questions that they might be embarrassed to ask in their content-area classrooms. Rather than using direct instruction, the AVID tutor acts as a facilitator, creating an environment where students are guiding one another through questioning and other inquiry-based activities. During the tutoring session, the tutor helps the students learn strategies and problem solving skills rather than attending to a specific homework problem or reading assignment. The AVID Director explained that the strategies used in the tutoring session along with curriculum addressed in the AVID elective course are meant to promote college and career readiness with the belief that these core skills are transferable and applicable to other learning experiences in and out of school. At the end of the tutoring session, the students reflect not only on what they learned but also why, drawing their thinking toward the process of learning and awareness of how that learning occurs.

\section{Tutors}

To be an AVID tutor, certain requirements need to be met. Although some exceptions may be made, most AVID tutors are active college students with at least 12 semester hours of college credit and a GPA of 2.5 or greater. Since tutors need appropriate training to be successful (Lin et al., 2015), AVID requires at least 12 hours of tutor training. The tutor also needs to be available several hours per week. The AVID director prefers the tutors keep consistent schedules and hours, which is critical to developing a rapport with students and therefore increases the likelihood of student success (Hetzel, Newcomb, \& Fuller, 2009; Ragonis \& Hazzan, 2009). AVID tutors work during and after regular school hours, earn around $\$ 15$ an hour, and typically work with middle school or high school students under the supervision of an AVID teacher.

\section{Method}


Due to the nature of the research questions and the need to explore individual participant experiences, a qualitative methodology was chosen for the research design. The following sections describe the methods of data collection, the demographics of the research participants, and the process for data analysis.

\section{Participants}

The participants for this research study were either recent college graduates or in the student teaching phase of the teacher preparation program at a Midwestern university. Each participant served as an AVID tutor while participating in either an undergraduate or graduate teacher licensing program. At the time of the research, only one school district in the region implemented an AVID program. A total of 13 participants were part of the study. Each participant completed a short questionnaire to provide demographic information. This information is reported in Table 1. Of the 13 participants, nine were female and four were male. Eleven of the participants were white and two were Native American. At the time of the interview, ten of the participants were still pre-service teachers and three were in-service teachers. The certification level and content area, as well as the grade level and content area in for which they tutored, varied among the participants. The participants were an AVID tutor ranging from two to 6 semesters, with an average of four semesters. The participants tutored for an average of 3.2 hours per week.

\section{Data Collection}

We interviewed the participants between spring 2012 and fall of 2016. All participants were currently an AVID tutor or had been at some point during their teacher preparation program. The interviews took place either on the university campus or at the participant's school site. Interviews were conducted with participants either individually or groups of two or three. 
Participants received a small payment for their time. Interviews were semi-structured to allow a formal, but flexible, approach to gather data. To collect information about various aspects of the tutors' experiences with the AVID program, the researchers used guiding questions to facilitate the discussion. If the participant mentioned something of particular interest to the study, the researchers would probe that area to deepen the level of understanding. Each interview lasted approximately one hour and was audio recorded. Interviews were then transcribed by a professional with experience in transcriptions to ensure quality and accuracy of the data analysis process. The researchers also conducted an interview with the AVID coordinator. At the time of the interview, this individual served as the district's AVID Director as well as the Dean of Students at one of the district's middle schools. The main role of the AVID director was to recruit, train, and coordinate all the placements of the tutors. They also provided continued support for the tutors if additional resources and training was needed. The intent of this interview was used to offer a complementary perspective for the research. Results from the AVID director's interview are embedded throughout the results to corroborate the outcomes of the AVID tutors' interviews. 


\begin{tabular}{|c|c|c|c|c|c|c|c|c|c|c|c|c|c|}
\hline & \multicolumn{13}{|c|}{ Participants (pseudonyms) } \\
\hline & Ed & Keith & Deb & John & Jen & Josh & Renee & Sue & Julie & Tess & Ellen & Sam & Ashley \\
\hline Gender & Male & Male & Female & Male & Female & Male & Female & Female & Female & Female & Female & Female & Female \\
\hline Ethnicity & White & White & White & White & White & White & Na. Am. & White & White & Na. Am. & White & White & White \\
\hline Service & Pre- & Pre- & Pre- & Pre- & Pre- & Pre- & In- & In- & Pre- & Pre- & Pre- & Pre- & In- \\
\hline Cert. Level & HS & $\begin{array}{c}\text { MS/ } \\
\text { HS }\end{array}$ & $\begin{array}{l}\text { MS/ } \\
\text { HS }\end{array}$ & HS & $\begin{array}{l}\text { MS/ } \\
\mathrm{HS}\end{array}$ & $\begin{array}{l}\text { MS/ } \\
\text { HS }\end{array}$ & MS & $\begin{array}{l}\text { MS/ } \\
\text { HS }\end{array}$ & $\begin{array}{l}\text { MS/ } \\
\text { HS }\end{array}$ & $\begin{array}{l}\text { MS/ } \\
\text { HS }\end{array}$ & $\begin{array}{l}\text { MS/ } \\
\text { HS }\end{array}$ & $\begin{array}{l}\text { MS/ } \\
\text { HS }\end{array}$ & $\begin{array}{l}\text { MS/ } \\
\text { HS }\end{array}$ \\
\hline Cert. Area & LA & LS & Math & LA & Math & Math & SS & LA & SS & LA & Math & SS & LS \\
\hline $\begin{array}{l}\text { Sem. as } \\
\text { AVID Tutor }\end{array}$ & 3 & 3 & 2 & 4 & 4 & 5 & 6 & 5 & 6 & 4 & 5 & 3 & 3 \\
\hline $\begin{array}{l}\text { AVID Grade } \\
\text { Level }\end{array}$ & $8-11$ & $8-9$ & 7 & $7-10$ & $7-9$ & $7-10$ & 7 & $7-9$ & $6-11$ & $7-11$ & $8-11$ & $7-11$ & $7-10$ \\
\hline $\begin{array}{l}\text { Avg. AVID } \\
\text { hrs/week }\end{array}$ & 2.5 & 2 & 2 & 6.5 & 2.5 & 3 & 3.5 & 3 & 3 & 3 & 4 & 3 & 4 \\
\hline Avg. \# / class & 10 & 30 & 6 & 25 & 30 & 6 & 23 & 20 & 6 & 25 & 6 & 25 & 7 \\
\hline ST Level & HS & MS & HS & HS & HS & HS & MS & HS & MS & MS & MS & MS & MS \\
\hline ST Area & LA & $\begin{array}{c}\text { LS/ } \\
\text { AVID }\end{array}$ & Math & LA & Math & Math & $\mathrm{SS}$ & LA & SS & LA & Math & SS & LS \\
\hline $\begin{array}{l}\text { ST w/ AVID } \\
\text { Teacher }\end{array}$ & No & Yes & No & No & No & Yes & Yes & No & No & No & No & Yes & No \\
\hline
\end{tabular}

Cert. = Certification; Sem. $=$ Semesters; ST = Student Teaching; Na. Am. = Native American; Pre- = Pre-Service Teacher; In- = In-Service Teacher; HS = High School; MS = Middle School; LA = Language Arts; LS = Life Science; SS = Social Science 


\section{Interview Protocol}

\section{How did you develop this and how was it validated?}

\section{Data Analysis}

A qualitative methodology was chosen due to the format of the research question and the need to explore the nature of the experiences of the tutors. We sought to develop a detailed description of the experiences of an AVID tutor, and to engage as active learners "telling the story from the participants' view" (Creswell, 1998, p. 18). The study began with the original research question, "What impact did AVID tutoring have on tutors in the formation of a teacher identity?" Through the course of the study, additional areas of interest and questions emerged, including, "Why did the pre-service teacher choose to become a tutor?", and "What did they learn from this experience?"

During the first round of analysis, interview transcripts were read and studied multiple times. All interview content was coded without discrimination, following Strauss and Corbin's (1990) open coding process of “...breaking down and conceptualizing...taking apart an observation, a sentence, a paragraph, and giving each discrete incident, idea, or event, a name, something that stands for or represents a phenomenon" (p. 63). Through this process, the researchers explored and categorized the data to seek differences and commonalities that may bear out as patterns. Detailed coding notes were kept during the analysis process to define concepts and categories as well as document questions and emerging inferences.

Following the open coding, we grouped the concepts into provisional categories, pulling together groups of concepts using a more abstract label. For example, the tutors talked about ideas, strategies and techniques they learned in their university coursework that they tried out during tutoring sessions. These concepts were grouped into a category named "theory into 
practice" because they were transferring abstract (or theoretical) ideas heard and read about in a university class to actual practice with students. The analysis process was completed by thoroughly reading and re-reading the coded interviews and the researchers engaging in extensive discussions. The interviews yielded a vast amount of data, with some relevant to this study and some useful in laying groundwork for future studies. Therefore, during the last step of analysis, the research question was used to filter the categories for relevance for this study.

\section{Trustworthiness and Credibility}

Please write about this about your study.

\section{Findings}

Beijaard et al. (2004) identified four components of teacher identity: content knowledge, pedagogical practices, relationships with students, and engagement with colleagues. The participants in this study focused extensively on their pedagogical learning, while relationships with students and colleagues emerged to a lesser degree. Content knowledge did not emerge as an area of teacher identity development during or because of tutoring for the participants in this study; therefore, this section will begin with findings related to pedagogical practices followed by relationships with students and relationships with colleagues.

\section{Pedagogical Practices}

During interviews, the tutors described their pedagogical knowledge in terms of AVID tutoring and not the entirety of their learning through their teacher preparation program.

Pedagogical knowledge was classified into two categories: classroom-to-tutoring connections and tutoring-to-classroom connections.

A classroom-to-tutoring connection occurred when the tutor transferred learning from the university classroom to tutoring. Jen explained that tutoring "helped to reinforce what we were 
learning in our classes." The most salient transfer occurred with tutoring session management. Several of the tutors described using techniques learned in their classroom management course. Josh stated, "Definitely the classroom management aspect...especially time management, which is always a very important aspect in [tutorials]." Renee provided a specific example: "Even the basic things like proximity management method. I would hear about it in class, and then the next week in tutorials I'd be like, 'Hey, why don't you come sit in this desk right next to me.'” Renee's explanation was echoed by Sue: "I can remember some very specific moments where I'd hear something in class and be like, 'Oh, that's what I should have done in [tutorials] last week." In addition, Ed explained how he applied levels of behavior intervention: "I remember thinking, 'make eye contact.' I remember trying to apply that." Several tutors said they wished they had completed the classroom management class sooner because of its usefulness during tutoring sessions.

A tutoring-to-classroom connection occurred when the tutors were able to better understand content they were learning in their university coursework because of AVID experiences. Renee explained, "I could bring a lot of examples from tutoring to class discussions, and things that I also felt were very valuable because I had this experience with students that I could share." Ed reflected on the extended learning that occurred when he could use tutoring experiences to contextualize course content. He stated, "I think it kind of just took the idea one step further for us. Having the definition and understanding it and then getting to actually see it in action. I think that really helps." John confirmed this impact as well, when he shared that, "[Tutorials] helped to reinforce what we were learning in our classes." Ashley described getting to use reading strategies she read about in a content area reading course. She stated, "I got to see critical reading strategies....and Cornell notes." 
Some tutors did not readily make connections, made superficial connections, or only made connections retrospectively when prompted by the researchers. Keith stated, "There weren't any major alignments other than just coincidental ones." When asked specifically if he saw any connections between Cornell note taking and strategies presented in a content area reading course, Josh explained he saw students determining important information: "Each time you ask a student to go back and look at their notes or in their book, they have to be able to look through the information to determine what is needed for this problem." After prompting, Jen said she did "not so much" make connections to her classroom management course "because [AVID] was a smaller group." She referred to connecting to "development," but was not able to provide an example or deeper explanation.

The data revealed limited connections to instructional strategies, assessment practices, and developmental needs of students. Ed made a connection to readiness for learning but could not connect it to a particular course or university-based content. He stated, "I'd remember kind of noticing 'Oh, the reason you can't think like that is because you're not that far in your development yet."' Keith was able to make a connection to learning from his science methods course, but he was the only tutor who mentioned a content specialty methods course during interviews. According to Keith:

It's a problem where people have so many preconceived notions of things with space and physics. It's just a train of thought for most people to think something is this way when it's really not. I saw that, I guess, in some of the questions in AVID tutoring. A student would be dead set in their thinking, and the kids would try to explain it, and they'd kind of look like they were getting it and then all of a sudden [say] "Well, no," because they already believed a certain way, and they just couldn't get over that. 
Along with the transfer of learning, tutors were provided the opportunity to learn how to teach and practice being a teacher that went beyond their teacher preparation program. The tutors described moving from holding a textbook-derived definition for practices including classroom management, grading, and teacher questioning to break-through experiences that allowed them to witness and then enact these practices. Sam described how she thought about AVID tutoring in regard to answering student questions:

I've tutored before; it was more like a kid comes in, they have homework, and you'd help them. [AVID] wasn't like that. It was more of a class, so I felt more like a teacher than a tutor, if that makes any sense. I was teaching them thinking strategies. It wasn't just like, "Oh, here's your homework problem. Let me help you get to the answer." Sue noted that tutoring taught her more than instructional strategies. She explained:

One thing I took away from AVID tutoring that maybe I couldn't in my education courses was developing relationships with the students. Seeing that firsthand isn't something that you can learn in an education course, and I really took that away. Josh explained that tutoring helped him realize he needed to set explicit expectations, "Once I started, for a while, I started making expectations more for me to make sure students were on task." John confirmed the opportunity tutoring afforded to practice grading: "[AVID tutoring] was a good experience for grading of assignments, giving feedback and stuff."

The AVID tutoring experience also enabled learning about teaching that went beyond university coursework. Ed described learning "to teach [students] in a way that's going to work" through the use of verbal cues "to avoid spoon feeding answers." He went on to explain, "As an AVID tutor, you were trained to use those guiding questions, and without that I might not have known as much about that process." He then inferred the impact this would have on his teaching 
practice, "Maybe now in my student teaching, [I would] just ask the students the questions, and if they didn't know, I'd be, 'Here's the answer,' and not really know how to use that guiding question process." Ashley also spoke of AVID tutoring helping her to learn ways to ask higher level thinking questions. She explained, "We witnessed student confusion. AVID helped me identify a point of confusion and refine that to a specific question."

Impact on pedagogical practices emerged as the most robust category in the data. Tutors identified connections they made while tutoring to learning in their teacher preparation coursework and connections they made in courses to experiences they had tutoring. Tutors also identified new pedagogical learning through AVID tutoring.

\section{Relationships with Students}

Tutors talked about relationships with students in different ways. Several shared that working with the students helped them confirm or make the decision to be a teacher. In addition, nearly all the tutors referenced gaining experience to improve their teaching skills.

Most of the tutors began with AVID in their sophomore or junior year while still in the early stages of teacher preparation; therefore, some were still exploring whether or not they wanted to be a teacher, and some, although admitted to the preparation program, had not yet solidified that decision. The tutors talked about their experiences working with students as helping them to make that decision. Ashley stated, "Tutoring helped me see, 'Yes, I want to be a teacher." She followed up with, "It helps you determine if you truly love working with students." Sam drew similar conclusions about her tutoring experiences:

It helped me cement in my mind that, yes, I do want to be a teacher. Because while your taking classes you don't have too much experience with kids like even when you go out for practicum hours or observation you're not really working with the kids [through 
AVID] I was able to work with them, and it made me feel like I really enjoyed this. It's something I definitely want to do.

Several of the tutors said their experiences working with students at the middle level changed preconceived notions they had about middle level students, and for some, helped them determine they wanted to be middle level teachers. For example, Deb had made the decision to be a teacher, but she did not yet know what level was her best fit. Tutoring helped Deb discover her true passion was working with middle level students. She stated, "I already knew I wanted to be a teacher. I didn't know what level and that really influenced my decision to take the middle school classes just so that I had that option." She went on to explain how tutoring helped her make the decision:

It was my first time working with like the junior high age. I was with 7 th graders because I had worked with younger kids a lot more, and it kind of opened my eyes to what middle-schoolers are like. I actually really liked working with them, and I could see myself getting a career with that age level. It really helped me see that I actually like that level.

During the small group interview, Ed agreed with Deb, sharing that he had not considered teaching at the middle level until he was placed with eighth grade students for tutoring: "You don't know if you've never done it so that helped me." Julie said experience with students changed her thinking about middle level. She joked, "Ok, maybe they're not so bad."

Most of the tutors talked about how the AVID tutoring model enabled the building of relationships. Ashley explained, "I got a chance to work with a micro-classroom. You get academic experience, but don't have to work with a big group. You work with 5-7 and really get to know those students. It helps you determine if you truly love working with students." The 
tutors also noted the additional time spent tutoring meant more time with students. Julie said, "That extra time with the kids was definitely in our favor." Renee went further with this idea. She said, 'It's just valuable to be around kids because the more that you're around them, the more comfortable you are with them." Keith, Ed, and John named experience working with students as one of the most beneficial aspects of AVID tutoring.

Sue student taught in the same building where she had been a tutor, and she appreciated the relationships that were already in place because of the tutoring experience. She explained:

Lots of times I'll know some of the kids already, and that makes it really nice because when I started at [school], some of my AVID kids were at school. They'd see me in the hall and then they'd have that moment where it's like "Hi [name]." And I think that just makes it a better environment for your first student teaching experience.

The responsibility tutors expressed for "their" students is additional evidence of relationship building. During interviews, the tutors often referred to students as "my kids" or "my students." For example, Sam described taking additional steps to ensure their learning needs were being met. She said her tutees were "feeling lost" in their math class, so she sought out the math teacher. Sam shared what she said to him: "The kids are really struggling with this problem. They just don't know - they're getting confused about step three that you showed them, so maybe in class you might want to re-go over that." Sam's conversation with the math teacher also demonstrates the relationships the tutors established with other teachers in the school.

\section{Relationships with Colleagues}

Tutors talked about relationships with colleagues in seven of the eight interview sessions; however, this topic took a relatively small portion of the interview time. Tutors noted that the structure of AVID tutoring provided limited time and opportunity for tutors to interact with 
teachers. When asked if she had an opportunity to collaborate with teachers through AVID tutoring, Sam explained that tutoring time focused on the students: "There wasn't really any time to meet before-hand or after-hand to really talk about what was going on. Sometimes there was, but really there's not much time to really talk to the teachers." Josh described occasional interactions with teachers: "I did talk with the AVID teachers occasionally, and we made sure that we were on the same page."

Despite the lack of time for interaction, nearly all the tutors said AVID tutoring allowed them to network and "get my name out there." John explained that he intentionally tutored at several different grade levels in different buildings in the school district: "[I got] to see a lot of teachers and then go back sometimes for observations and see them again. So it was good connections, definitely." The tutors also learned that being an AVID tutor carried a benefit with educators in the district, possibly elevating their reputation. Sam explained:

I know some teachers at [school] for practicum hours and observation hours they only accept AVID tutors because some teachers told me that a lot of kids they get who are just going for observation or practicum just kind of sit in the back. They're unprofessional or something like that. So they only ask for AVID tutors because they're always professional, they're on time, and when they're in the classroom, they get engaged right away. They don't just sit back.

The interview data revealed that the AVID tutoring model supported development of teacher identity across three of the four components (Beijaard et al., 2004): pedagogical practices, relationships with students, and - to a lesser degree-relationships with teachers. Pedagogical practices emerged as the most impactful point of development based on tutor 
experiences. The following section will explore the pedagogical connections tutors made and how this contributed to their development of teacher identity.

\section{Discussion}

Teacher preparation programs require field experiences with the intent that these experiences will allow candidates to observe strategies being presented in university coursework and allow the candidates to practice being teachers (Massey \& Lewis, 2011). In line with the 11 AVID Essentials (2017), AVID tutoring is not required for teacher candidates in this preparation program; however, because of the prevalence among pre-service teachers in the program, we sought to determine what role AVID tutoring played in the development of those who participated.

\section{Connections}

During interviews, most of the tutors did not spontaneously identify connections between their university coursework and AVID, but when asked, with the exception of one, all were able to describe meaningful connections. The awareness of learning that occurred through the tutorial experience was not the aha or light-bulb moment those who prepare educators romanticize about. Rather, the awareness required reflection, prompting, and explicitly supported connections and transfer for several of the tutors. The tutors could describe the process and speak in sophisticated ways about teaching, but the researchers suspect they were still in their metacognitive journey toward full awareness of what they knew.

The AVID tutoring experience appears to have provided scaffolding for the tutors to move toward deeper levels of development of their teacher identities than they previously had based upon only hearing about or reading a definition for a concept or strategy in university coursework. The scaffolding provided by AVID tutoring seems to extend beyond the 
opportunity identified by Massey and Lewis (2011) for tutoring to provide a real-world setting for practice. AVID tutoring allowed the tutors to identify the concept or strategy in action and move into applying concepts or strategies. For example, Renee described the process of learning about the use of proximity in her classroom management class. She recognized an opportunity to use it based on the behavior of one of her tutees, and then applied the strategy during a tutoring session. The additional classroom time offered through AVID tutoring seemed to accelerate the tutors' thinking about teaching and learning, pushing them to be more active thinkers about the content in their university coursework, and allowing them to make meaningful connections and ask questions about what might apply to their tutoring sessions. In addition, there were elements of teaching the tutors did not recognize in their required programmatic field experiences that they did recognize while tutoring. During tutoring, they were actively engaged and responsible for student learning, raising the relevance of the learning experience, which echoes the findings of Galbraith and Winterbottom (2011).

\section{Development of Teacher Identity}

Having the opportunity to practice teaching influenced teaching practice for the tutors. As described by Trent (2010) and Walkington (2005), the development of teacher identity is a constantly evolving process. During interviews, the tutors revealed grappling with core paradigms. One such example was the evolving understanding of student-centered teaching and the way pedagogical practices differ fundamentally in teacher-centered and student-centered classrooms. The term student-centered is repeated often in teacher-preparation courses, but despite its deceptively simple definition, it is a highly complex concept that is challenging for many teachers to enact. Most of the tutors described developing teacher identity as a studentcentered teacher. Chong et al. (2011) and Izadinia (2013) described a similar process of tutors 
using their experiences to determine what kind of teacher they wanted to be. Ed talked about how tutoring helped him define his teaching philosophy: "[Tutoring] personally, shaped my teaching philosophy a lot. Just seeing that student-centered activity at work and seeing how well it works for those kids, it's kind of nice being able to sit back and facilitate." Deb described experiencing transformative thinking during tutoring that allowed her to assign concrete pedagogical practices to either a teacher-centered or student-centered orientation. She stated, "Student-centered is when students are actually discovering or they're discussing with their peers...the teacher is just facilitating everything." She went on to classify lecturing and "giving the students all the information" as teacher-centered practices. Josh shifted paradigms when he realized students learn more when they are directing the learning. He explained:

[I] always thought [teaching] has to be through just direct instruction or maybe group work, and you realize that if you give these students enough prior knowledge on subject material that they can solve problems with the help of peers or even by themselves...the AVID experience has taught me that they can always find the answer within them. They just need a push in the right direction.

Sam also experienced insight related to a student-centered approach to teaching:

Oh, my gosh, [I learned] so much, just the power of questioning and getting the students to learn on their own. Because if you teach them how to do that, then they don't really need a teacher too much. For me, when I was there, the best sessions in my mind were when I didn't say anything, and they did the work. It showed that they were learning how to learn on their own, which is good because they're not always going to have a teacher next to them when they're doing their homework at night, or even when they're in the classroom, you know, one teacher per 20 students. 
For Sue, the paradigm shift occurred through practice as she tried out the questioning strategy she learned in tutorials while student teaching. She stated, "I didn't really lecture; I just asked a bunch of questions, and of course, differentiated questions, and I learned all that through AVID." She followed up by explaining:

Then, if they didn't know the answer, [I would prompt], "Think about this," and then I would tell them a sort of think-aloud using an analyzing process so they can know, "Oh, in order to answer this question, I have to think this way."

Ashley went further in defining her student-centered teaching approach, identifying whole-child teaching under the student-centered paradigm, where the teacher is a "support person." She went on stating that, “[Cooperating Teacher], for example, was so intentional. Like, if students weren't turning in work...she would sit down and talk with them to make a success plan." Ashley was able to internalize the meaning behind her AVID teacher's actions to identify pedagogical practices that will become part of her own teaching identify.

As noted by DeFeo and Caparas (2014), the tutors in this study reported relationships with students and time in the school as beneficial. They described using these experiences to make career-related decisions about teaching as well as increase their commitment to the students. This commitment came through in tutor references to "my students" and the extra steps taken to ensure student needs were met. These tutors became part of the school community, taking responsibility for the students alongside the in-service teachers. Relationships with teachers also emerged as an important component of the AVID tutoring experience, albeit to a lesser degree than development of pedagogical knowledge. The interactions helped the tutors to understand the school context and students (DeFeo \& Caparas, 2014) and check their practices with an expert for increased confidence (Bar-Eli et al., 1998). 
Lastly, although content knowledge did not emerge as an area of development within teacher identity for the tutors in this study, it is important to explore why that may be. The researchers believe it can be explained through the AVID tutoring model. AVID tutoring is not like traditional tutoring, where a tutor acts as a content expert to provide a student with an answer to a content question. Rather, AVID tutors facilitate a thinking process among the 5-7 students in the tutoring group. The AVID tutors support students in finding answers to their questions, which does not necessitate content expertise. AVID tutors require pedagogical skills to manage the small group and ask critical thinking questions, explaining the extensive focus the tutors had during interviews.

\section{Recommendations}

Most of the tutors in this study did not independently make connections or transfer learning between their tutoring experience and their university coursework. With this in mind, teacher preparation programs need to be intentional in supporting teacher candidates in making connections between tutoring experiences and university course content. Many of the tutors were able to recognize intersections between their university coursework and tutoring experiences, but not all were able to make these connections without prompting or even with prompting, because of the lack of connections, there were many missed opportunities for crosspollination between tutoring and coursework. Kyle's statement demonstrated these missed opportunities, “There weren't any major alignments other than just coincidental ones." This statement also speaks to the opportunity teacher education faculty have for planning with schoolbased educators who work in programs like AVID. Deeper understanding of these programs will allow faculty to design their courses to maximize both experiences for pre-service teachers. Lastly, we highlighted the importance of field experiences that approximate as closely as 
possible being a teacher. Multiple researchers (e.g., Beltman et al., 2011; Izadinia, 2013;

Mansfield et al., 2014) have made this same claim, calling for carefully timed and well-planned experiences for pre-service teachers. We have demonstrated the potential for teacher preparation faculty to not only set up opportunities for pre-service teachers to make connections, but also help them explore these connections to extend and deepen the development of their teacher identity.

\section{Opportunities for Further Research}

Like most studies, this experience raised additional questions for us, as researchers. We wondered if AVID tutoring may accelerated the development of teacher identity. Further research could compare preservice teachers who participated in AVID tutoring with those who did not during student teaching or their first year of teaching using Beijaard's teacher identity framework. Further research could also include observations of AVID tutoring sessions to supplement tutor perceptions with evidence of action. Finally, we wondered if memory loss could have impacted the connections made by tutors in this study. Tutor perceptions could be collected in close proximity of a tutoring session over time to capture examples and perceptions while fresh in the memories of the tutors.

\section{References}

Advancement Via Individual Determination (AVID). (2017). Retrieved on April 12, 2017 from http://www.avid.org/

Advancement Via Individual Determination (AVID). (2018). Retrieved on April 4, 2018 from http://www.avid.org/what-avid-is 
Bar-Eli, N., Bar-Eli, M., Tenenbaum, G., \& Forlin, C. (1998). The tutoring process and its manifestation in the classroom behaviour of tutors and tutees. British Educational Research Journal, 24(3), 283-300.

Beauchamp, C., \& Thomas, L. (2009). Understanding teacher identity: An overview of issues in the literature and implications for teacher education. Cambridge Journal of Education, $39(2), 175-189$.

Beijaard, D., Meijer, P. C., \& Verloop, N. (2004). Reconsidering research on teachers' professional identity. Teaching and Teacher Education, 20(2), 107-128.

Beltman, S., Mansfield, C., \& Price, A. (2011). Thriving not just surviving: A review of research on teacher resilience. Educational Research Review, 6(3), 185-207. http://dx.doi.org/10.1016/j.edurev.2011.09.001

Chong, S., Low, E. L., \& Goh, K. C. (2011). Developing student teachers' professional identities - An exploratory study. International Education Studies, 4(1), 30-38.

Cohen, P. A., Kulik, J. A., \& Kulik, C. C. (1982). Educational outcomes of tutoring: A metaanalysis of findings. American Educational Research Journal, 19(2), 237-248.

Creswell, J. W. (1998). Qualitative inquiry and research design: Choosing among five traditions. Thousand Oaks, CA: Sage Publications.

Danielewicz, J. (2001). Teaching selves: Identity, pedagogy, and teacher education. Albany, NY: State University of New York Press.

DeFeo, D. J., \& Caparas, F. (2014). Tutoring as transformative work: A phenomenological case study of tutors' experiences. Journal of College Reading and Learning, 44(2), 141-163. 
Findlay, K. (2006). Context and learning factors in the development of teacher identity: A case study of newly qualified teachers during their induction year. Journal of In-service Education, 32(4), 511-532.

Galbraith, J., \& Winterbottom, M. (2011). Peer-tutoring: What's in it for the tutor? Educational Studies, 37(3), 321-332.

Gee, J. P. (2000). Identity as an analytical lens for research in education. Review of Research in Education, 25(1), 99-125.

Hammerness, K., Darling-Hammond, L., \& Bransford, J. (2005). How teachers learn and develop. In L. Darling-Hammond \& J. Bransford (Eds.), Preparing teachers for a changing world: What teachers should learn and be able to do (pp. 358-389). San Francisco, CA: Jossey-Bass.

Hetzel, J., Newcomb, S., \& Fuller, J. (2009). Tutoring initiative: A high school/university partnership. The Delta Kappa Gamma Bulletin, 76(1), 9-13.

Huerta, J. J., Watt, K. M., \& Butcher, J. T. (2013). Examining Advancement Via Individual Determination (AVID) and its impact on middle school rigor and student preparedness. American Secondary Education, 41(2), 24-37.

Izadinia, M. (2013). A review of research on student teachers' professional identity. British Educational Research Journal, 39(4), 694-713.

Lane, B., Hudson, R. F., McCray, E. D., Tragash, J. R, \& Zeig, J. L. (2011). Tutoring opened my eyes: Tutor experiences in the america reads challenge. Mentoring \& Tutoring: Partnership in Learning, 19(2), 199-218. 
Lin, L. C., Lin, H., \& Lu, T. (2015). Online tutoring service for enriching college students' experience in community engagement. Procedia - Social and Behavioral Sciences, 191(2), 1676-1681.

Maclean, R., \& White, S. (2007). Video reflection and the formation of teacher identity in a team of pre-service and experienced teachers. Reflective Practice, 8(1), 47-60.

Mansfield, C. F., Beltman, S., \& Price, A. (2014). 'I'm coming back again!' The resilience process of early career teachers. Teachers and Teaching: Theory and Practice, 20(5), 547-567. http://dx.doi.org/10.1080/13540602.2014.937958

Massey, D. D., \& Lewis, J. L. (2011). Learning from the "Little Guys": What do middle and high school pre-service teachers learn from tutoring elementary students? Literacy Research and Instruction, 50(2), 120-132.

Mayer, D. (1999). Building teaching identities: Implications for pre-service teacher education, Paper presented to the Australian Association for Research in Education, Melbourne.

Olsen, B. (2008). Reasons for entry into the profession illuminate teacher identity development. Teacher Education Quarterly, 35(3), 23-40.

Pillen, M., Beijaard, D., \& den Brok, P. (2013). Tensions in beginning teachers' professional identity development, accompanying feelings and coping strategies. European Journal of Teacher Education, 36(3), 240-260. http://dx.doi.org/10.1080/02619768.2012.696192

Putnam, R. T., \& Borko, H. (2000). What do new views of knowledge and thinking have to say about research on teacher learning? Educational Researcher, 29(1), 4-15.

Ragonis, N., \& Hazzan, O. (2009). A tutoring model for promoting the pedagogical-disciplinary skills of prospective teachers. Mentoring \& Tutoring: Partnership in Learning, 17(1), 6782. 
Rodgers, C. R., \& Scott, K. H. (2008). The development of the personal self and professional identity in learning to teach. In M. Cochran-Smith, S. Feiman-Nemser, D. J. McIntyre, \& K.E. Demers (Eds.), Handbook of research on teacher education: Ensuring questions in changing contexts (pp. 732-755). New York, NY: Routledge.

Rothman, T., \& Henderson, M. (2011). Do school-based tutoring programs significantly improve student performance on standardized tests? Research in Middle Level Education, 34(6), 1-10.

Schepens, A., Aelterman, A., \& Vlerick, P. (2009). Student teachers' professional identity formation: Between being born as a teacher and becoming one. Educational Studies, 35(4), 361-378.

Smagorinsky, P., Cook, L. S., Moore, C., Jackson, A. Y., \& Fry, P. G. (2004). Tensions in learning to teach: Accommodation and development of a teaching identity. Journal of Teacher Education, 55(1), 8-24.

Strauss, A. L., \& Corbin, J. M. (1990). Basics of qualitative research: Grounded theory procedures and techniques. Newbury Park, CA: Sage Publications.

Trent, J. (2010). Teacher education as identity construction: Insights from action research. Journal of Education for Teaching, 36(2), 53-168.

Walkington, J. (2005). Becoming a teacher: Encouraging development of teacher identity through reflective practice. Asia-Pacific Journal of Teacher Education, 33(1), 53-64.

Watt, K. M., Huerta, J., \& Lozano, A. (2007). A comparison study of AVID and GEAR UP 10th-grade students in two high schools in the Rio Grande Valley of Texas. Journal of Education for Students Placed at Risk, 12(2), 1-29. 
Watt, K. M., Huerta, J. J., \& Mills, S. J. (2010a). Advancement Via Individual Determination (AVID) professional development as a predictor of teacher leadership in the United States. Professional Development in Education, 36(1), 1-16.

Watt, K. M., Huerta, J. J., \& Mills, S. J. (2010b). The impact of AVID professional development on teacher perceptions of school culture and climate in the United States. International Journal of Educational Reform, 19(3), 172-184.

Watt, K. M., Powell, C. A, \& Mendiola, I. D. (2004). Implications of one comprehensive school reform model for secondary school students underrepresented in higher education. Journal of Education for Students Placed At Risk, 9(3), 241-259.

Watt, K. M., Powell, C. A., Mendiola, I. D., \& Cossio G. (2006). Schoolwide impact and AVID: How have selected Texas high schools addressed the new accountability measures? Journal of Education for Students Placed At Risk, 11(1), 55-73.

Watt, K. M., Yanez, D., \& Cossio, G. (2002). AVID: A comprehensive school reform model for Texas. National Forum of Educational Administration and Supervision Journal, 19(3), 43-59.

Wideen, M., Mayer-Smith, J., \& Moon, B. (1998). A critical analysis of the research on learning to teach: Making the case for an ecological perspective on inquiry. Review of Educational Research, 68(2), 130-178.

Note: The authors have no financial interest or benefit from this research. 